\title{
Peningkatan Produktivitas Ibu Rumah Tangga Di Bukit Mekar Wangi Melalui Sistem Hidroponik
}

\author{
Anelia Pratiwi ${ }^{1 *}$, Ari Putra ${ }^{1}$, Olen Okta Reza ${ }^{1}$ \\ ${ }^{1}$ Program studi Pendidikan Masyarakat, Fakultas Keguruan dan Ilmu Pendidikan, Universitas Ibn \\ Khaldun Bogor, Jl. K.H. Sholeh Iskandar Raya Km. 2, Kedung Badak, Bogor 16161 \\ Email Penulis Korespondensi: aneliapratiwi0598@gmail.com
}

\begin{abstract}
This service program is carried out to empower housewives by utilizing narrow land by farming without using soil media, but using water media or hydroponics. To increase the productivity of housewives in utilizing narrow land with hydroponic activities. This service uses a Community Development approach that is oriented towards efforts to develop community empowerment by making the community both the subject and the object of development and involving them directly in various community service activities, the research subjects being housewives in Bukit Mekar Wangi. The results of this study are to increase the productivity of housewives in utilizing narrow land by using plastic bottles in increasing the knowledge and skills of mothers in Bukit Mekar Wangi Tanah Sareal, Bogor City to find out how to cultivate vegetable crops hydroponically, both from tools and equipment. and materials needed, how to sow, to the process of transferring seeds. Which previously the community had known for a long time Hydroponic activities without soil media and management service activities succeeded in increasing knowledge and improving the family economy.
\end{abstract}

Keywords: Empowerment of IRT, Hydroponics, Utilization of Narrow Land,

\begin{abstract}
Abstrak
Program pengabdian ini dilaksanakan dalam rangka memberdayakan ibu rumah tangga (IRT) dengan memenfaatkan lahan sempit dengan bercocok tanam tanpa mengunakan media tanah, melaikan mengunakan media air atau Hidroponik. Dengan tujuan untuk meningkatkan produktifitas ibu-ibu rumah tangga dalam memanfaatkan lahan sempit dengan kegiatan Hidroponik. Pengabdian ini menggunakan pendekatan Community Development pendekatan yang berorientasi kepada upayaupaya pengembangan pemberdayaan masyarakat dengan menjadikan masyarakat sebagai subyek dan sekaligus obyek pembangunan dan melibatkan mereka secara langsung dalam berbagai kegiatan pengabdian masyarakat, subjek penelitianya ibu-ibu rumah tangga di Bukit Mekar Wangi. Hasil dari penelitian ini yaitu untuk meningkatkan produktifitas ibu-ibu rumah tangga dalam memenfaatkan lahan sempit dengan mengunakan botol plastik dalam meningkatkan pengetahuan dan keterampilan ibu-ibu di Bukit Mekar Wangi Tanah Sareal Kota Bogor untuk mengetahui cara budi daya tanaman sayur secara hidroponik, baik dari alat dan bahan yang di butuhkan, cara menyemai, hingga sampai proses pemindahan benih. Yang mana sebelumnya masyarakat sudah mengetahuinya dari lama kegiatan Hidroponik tanpa media tanah dan kegiatan pengabdian pengelola berhasil meningkatkan pengetahuan dan untuk meningkatkan perekonomian keluarga.
\end{abstract}

Kata Kunci: Pemberdayaan IRT,Pemanfaatan Lahan Sempit, Hidroponik 


\section{PENDAHULUAN}

Pertumbuhan populasi manusia berkaitan langsung dengan pemenuhan kebutuhan hidup yang memanfaatkan hampir seluruh sumber daya alam. Manusia mencoba untuk memenuhi permintaan pangan yang terus meningkat melalui modernisasi dan mekanisme pertanian. Ada aspek positif dalam modernisasi pertanian seperti intensifikasi dan diversifikasi produksi, tetapi juga berkontribusi pada aspek negatif seperti dampak penggunaan pestisida dan insektisida terhadap kualitas lingkungan.

Semakin bertambahnya jumlah penduduk menyebabkan percepatan pembangunan infrastruktur di hampir seluruh wilayah Indonesia, mengakibatkan tempat tinggal yang semakin sempit dan terbatas. Sebagian besar wilayah Indonesia adalah lahan pertanian. Petani biasanya memanfaatkan lahan sebagai media Bertani, ini sudah menjadi hal yang biasa dalam dunia pertanian. Mengingat ketidakmampuan masyarakat dalam memanfaatkan lahan yang luas untuk pertanian, pada saat ini terdapat cara lain untuk memanfaatkan lahan yang sempit tersebut untuk mengembangkan hasil pertanian, dengan mengembangkan produk melalui budidaya hidroponik.

Sekarang ini banyak warga masyarakat Indonesia baik dari kalangan remaja, ibu-ibu bahkan bapak-bapak sedang antusias dengan bercocok tanam, menghabiskan waktu akhir pekan dengan mengurus tanaman dirumah. Banyak dari mereka yang hanya tau metode penanaman pohon menggunakan pupuk saja, tetapi nyatanya metode penanaman tidak hanya itu, diantarnaya menggunakan metode yang bernama hidroponik.

Hidroponik suatu sistem budidaya yang mengandalkan air dalam bercocok tanam tanpa tanah. Pada dasarnya bertanam secara hidroponik memiliki banyak keunggulan dibandingkan dengan media tanam lainnya. Selain itu, teknik ini bisa juga dilakukan di lahan yang terbatas dan lebih ramah lingkungan. (Wulansari, 2012)

Kini lahan sempit sudah tidak menjadi hambatan, menggunakan metode hidroponik bisa menghasilkan aneka tanaman yang sehat tanpa pestisida. Praktis dan mudah karena memanfaatkan air tanpa menggunakan tanah. Semua jenis tanaman dapat ditanam dengan sistem pertanian hidroponik, diantaranya: jenis tanaman sayur, jenis tanaman buah, jenis tanaman hias, dan jenis tanaman obat-obatan. Sedangkan jenis tanaman yang dapat ditanam dengan sistem hidroponik antaranya bunga (contohnya: krisan, gerberra, anggrek, kaktus), sayur - sayuran ( misal: selada, sawi, tomat, wortel, asparagus, brokoli, cabe, terong), buah - buahan ( contohnya: melon, tomat, mentimun, semangka, strawberi) dan juga umbi - umbian. Budidaya tanaman sayuran secara hidroponik dengan memanfaatkan botol plastik mampu membangkitkan tumbuhnya mata rantai usaha melalui penciptaan pemanfaatan sampah botol plastik dan peningkatan kesejahteraan dan kesehatan masyarakat. Hal ini dikaitkan dengan upaya pemerintah untuk meningkatkan kesehatan masyarakat melalui kesadaran mengkonsumsi sayuran.

Melalui kegiatan pengabdian ini diharapkan setiap ibu-ibu dapat bercocok tanam sayuran secara hidroponik dengan menggunakan bahan yang hemat biaya dan tempat. Hasil bercocok tanam dapat dipenuhi secara mandiri tanpa harus membeli kebutuhan sayur mayur sehingga mengurangi pengeluaran belanja rumah tangga. Selain itu juga dapat menciptakan lingkungan bersih dan sehat bebas sampah.

\section{METODE PELAKSANAAN}

Dalam pelaksanaan pengabdian masyarakat menggunakan pendekatan Community Development, yaitu pendekatan yang berorientasi kepada upaya-upaya pengembangan pemberdayaan masyarakat dengan menjadikan masyarakat sebagai subyek dan sekaligus obyek pembangunan dan melibatkan mereka secara langsung dalam berbagai kegiatan pengabdian masyarakat sebagai upaya meningkatkan peran serta mereka dalam pembangunan demi kepentingan mereka sendiri.

Metode pelaksanaan program pengabdian masyarakat yang digunakan adalah share pengetahuan, pelatihan, dan pendampingan. Peserta terdiri dari 10 orang ibu-ibu Perumahan Bukit Mekarwangi Kecamatan Tanah Sareal Kota Bogor. yang berkeinginan mengikuti.

\section{Waktu Dan Tempat}

Kegiatan pengabdian masyarakat ini berlokasi di Perumahan Bukit Mekarwangi Kecamatan 
Tanah Sareal Kota Bogor. Kegiatan dilaksanakan pada 29 November 2020. Sasarannya dalam pelatihan ini adalah ibu-ibu, warga Perumahan Bukit Mekarwangi Kecamatan Tanah Sareal Kota Bogor.
Alat dan bahan
Alat yang digunakan :
1. Plastik hitam
2. Net pot
3. Kain flanel
4. Rockwool
5. Botol plastik bekas ukuran $1,5 \mathrm{~L}$
6. Air
7. Pupuk kompos
8. Benih tanaman bayam dan pokcoy

\section{Langkah Pelaksanaan}

Tahapan pelaksanaan kegiatan penanaman sayur secara hidroponik dibagi menjadi tiga tahap, yaitu berbagi pengetahuan, praktik langsung di lapangan (pelatihan) dan pendampingan yang langsung dihibahkan kepada masing-masing peserta. Pelatihan yang dilakukan di antaranya cara menyemai atau persemaian bibit pokcoy menggunakan rockwool, membuat media dari botol bekas dan kain flannel yang sudah di isi air, memindahkan semaian kedalam botol. Cara yang di gunakan dalam pelatihan hidroponik ini yaitu cara yang sederhana, yang dapat di praktekakan ibu-ibu di tempat tinggal mereka menggunakan bahan dan peralatan yang ada dilingkungan tempat tinggal, dan tidak memerlukan banyak biaya juga tempat yang luas.

\section{HASIL DAN PEMBAHASAN}

Dalam mendukung usaha pemanfaatan lahan sempit dalam kegiatan pengabdian masyarakat melalui budidaya tanaman dengan sistem hidroponik guna meningkatkan produktivitas Ibu rumah tangga di Bukit Mekar Wangi. Adapun pencapaian pelaksanaan program pengabdian masyarakat adalah untuk meningkatkan kemampuan ibu-ibu rumah tangga mengenai cara bercocok tanam dengan sistem hidroponik berbasis ramah lingkungan melalui pemanfaatan sampah botol plastik. Peserta kegiatan ini terdiri dari 10 orang ibu-ibu Perumahan Bukit Mekarwangi Kecamatan Tanah Sareal Kota Bogor. Kegiatan dilakukan untuk menyampaikan suatu informasi yang meliputi: sistem bercocok tanam hidroponik, cara memanfatkan hidroponik pada lahan sempit, dan memanfaatkan sampah botol plastik yang ada untuk berbagai media tanamnya. Dalam penyampaian informasi ini penting diketahui oleh ibu-ibu untuk bisa memanfaatkan lahan sempit dengan mengoptimalkannya menjadi lahan bercocok tanam melalui sistem hidroponik.

Kegiatan pengabdian ini diikuti oleh 10 peserta. Pengabdian diberikan dalam bentuk demonstrasi dan praktek. Pengabdian masyarakat diikuti oleh ibu rumah tangga dengan latar belakang pendidikan akhir tingkat SMP dan SMA atau sederajat. Yang didiharapkan dari kegiatan ini agar mampu mendorong kemandirian ekonomi masyarakat melalui pemanfaatan sampah botol plastik yang ada disekitar tempat tinggal sebagai media tanam dilahan yang sempit untuk sistem penanaman hidroponik. Berdasarkan capaian kegiatan maka metode yang diterapkan untuk dapat penyelesaian permasalahan ibu-ibu adalah melalui program pengabdian.

Kegiatan penyuluhan ini diawali dengan penyampaian materi hidroponik oleh narasumber, penyampaian materi ini dilakukan untuk memberikan pamahaman kepada ibu-ibu secara teori. Bagi pemula, pemahaman tentang material hidroponik memiliki pengaruh yang besar terhadap teknik budidaya sayuran hidroponik. Penyampaian materi hidroponik selesai, dilanjutkan dengan demonstrasi pembuatan sistem hidroponik secara langsung.

Dilihat dari reaksi positif para peserta, para peserta yang mengikuti kegiatan program pengabdian menunjukkan antusiasme yang tinggi. Tanggapan positif ini terlihat dari partisipasi aktif ibu-ibu dalam memberikan jawaban dan pertanyaan terkait materi. Peserta juga berperan aktif dalam menabur bibit selada dan membuat peralatan hidroponik sederhana dari limbah botol plastik. Semua kegiatan dilaksanakan sesuai dengan jadwal yang telah ditetapkan dan juga dilaksanakan secara tertib.

\section{Tahap Evaluasi}

Tahap evaluasi dalam proses kegiatan penanaman sayur dengan sistem hidroponik dilakukan oleh pengelola dengan metode wawancara langsung dan mereview pemahaman peserta dari awal sampai akhir kegiatan. Program pengabdian ini telah berhasil mencapai tujuan yang ditetapkan. Hal ini dapat dilihat dengan pengetahuan dan keterampilan 
ibu-ibu yang meningkat dari sebelumnya.

Hal ini bisa terlihat dengan respon ibu-ibu setelah kegiatan, dimana pengelola selalu menjalin komunikasi ketika mengaplikasikan teknik yang mereka dapatkan. Sebagai kelanjutan program, pengelola memberikan bibit sayuran pokcoy dan bayam kepada ibu- ibu Perumahan Bukit Mekarwangi Kecamatan Tanah Sareal Kota Bogor untuk dapat di tanam dengan sistem hidroponik seperti yang sudah diajarkan dalam program pengabdian masyarakat.

\section{Faktor pendukung dan penghambat pemberdayaan masyarakat}

1. Faktor Pendukung

a. Tersedianya fasilitas yang cukup memadai

b. Bibit untuk menanam tanaman sayur

c. Motivasi dan minat yang tinggi dari ibuibu

d. kerjasama yang baik antara pengelola dengan ibu-ibu

2. Faktor Penghambat

a. Sedikitnya ibu-ibu yang ikut berpartisipasi

b. Cuaca yang tidak menentu yang memepengaruhi ibu- ibu dalam berpartisipasi.

\section{KESIMPULAN}

Hidroponik merupakan kegiatan pertanian yang tidak menggunakan media tanah, sehingga hidroponik merupakan kegiatan pertanian yang menggunakan air sebagai media pengganti tanah. Dengan cara ini, sistem pertanian hidroponik dapat memanfaatkan lahan yang sempit. Pertanian yang menggunakan sistem hidroponik tidak membutuhkan lahan yang luas dalam pelaksanaannya. Maka melalui program kegiatan pengabdian ini Ibu-ibu Perumahan Bukit Mekarwangi Kecamatan Tanah Sareal Kota Bogor sudah mengetahui cara budi daya tanaman sayur secara hidroponik, baik dari alat dan bahan yang dibutukan, cara menyemai, hingga sampai proses pemindahan benih. Sebenarnya warga sudah bercocok tanam sedari lama, pengelola sudah berhasil meningkatkan pengetahuan dan kemauan ibu-ibu untuk memanfaatkan sampah botol plastik yang ada sebagai media bercocok tanam hidroponik. Sehingga program kegiatan pengabdian difokuskan pada budidaya hidroponik. Pengabdian ini di harapkan bisa mencapai tujuan yang di ingin di capai sebelumnya dengan kegiatan Pemberdayaan Ibu
Rumah Tangga Di Bukit Mekarwangi Melalui Budi Daya Tanaman Sayur Dengan Sistem Hidroponik.

\section{UCAPAN TERIMAKASIH}

Terimakasih yang sebanyak- banyaknya kepada Prodi Pendidikan Masyarakat yang telah mengadakan PLP untuk mahasiswa semester 7, yang telah memfasilitasi tempat untuk menjalankan program pemberdayaan di Perumahan Bukit Mekarwangi Kecamatan Tanah Sareal Kota Bogor. Juga terimakasih kepada para dosen pembimbing atas ide dan gagasannya dalam program ini, juga ibu-ibu yang mengikuti program yang saya adakan.

\section{DAFTAR PUSTAKA}

Edwardi. (2017, April 1). http://bangka.tribunnews.com/2017/040 1/inilah-manfaat-bercocoktanamhidroponik .

Krismawati, A. (2012). Teknologi Hidroponik Dalam Pemanfaatan Lahan Pekarangan. Malang: BPTP.

Mandiri, T. K. (2010). Pedoman Budidaya Hidroponik. Bandung: (ID) : Nuansa Aulia.

Martopo, S. (1992). Pembangunan Berwawasan Lingkungan . Yogyakarta: PPLH UGM.

Pusat, B. P. (2017). Statistik Indonesia Tahun 2017. Jakarta Pusat: Badan pusat statistik.

Sugiyono. (2016). Metodologi Penelitian Pendidikan. Bandung: Alfabeta.

Swastika S, Y. A. (2018). Buku Petunjuk Teknis Budidaya Sayuran Hidroponik (Bertanam Tanpa Media Tanah). Riau (ID): Balai Pengkajian Teknologi Pertanian (BPTP) Balitbangtan Riau, Badan Penelitian dan Pengembangan Pertanian, Kementeria. Riau.

Wulansari, A. (2012). Pengaruh macam larutan nutrisi pada hidroponik sistem rakit apung terhadap perumbuhan dan hasil baby kailan (Brassica Oleranceae Var. Alboglabra). Solo : Universitas Sebelas maret surakarta 